\title{
THE ADVANTAGES AND DISADVANTAGES OF INCLUSIVE EDUCATION FROM THE PERSPECTIVE OF FUTURE TEACHERS
}

\author{
Ieva Margeviča-Grinberga \\ University of Latvia, Latvia \\ Ilze Šūmane \\ University of Latvia, Latvia
}

\begin{abstract}
In Latvia, inclusive education is relevant as seen in the past several decades, during which time society has developed a more comprehensive understanding of and made significant progress towards implementing inclusive education. Nevertheless, there is still a gap between the priorities of education policy and reality in educational institutions. The quality of education accorded to students is informed by the knowledge, understanding and experience of teachers in the implementation of concepts of inclusive education. The current study aimed at identifying the visions of prospective teachers (already working in schools) concerning inclusive education. To explore the experiences of future teachers, this qualitative study used narratives (i.e., written answers to open-ended discussion questions) of prospective teachers as a research strategy. The study team recruited participants at the University of Latvia, which included 61 students in the work-based teacher education study programme and 46 future preschool and primary school teachers. Therefore, the current study offers insight into how comprehensive education is implemented in Latvian schools. The results reveal a positive attitude on the concept of inclusive education among most prospective teachers. However, they have concerns about the quality of its implementation, which come as a consequence of limited resources (human, time and financial) and the underdeveloped teachers' professional competence in the implementation of diversity solutions. Therefore, improving the study process of future teachers enhances the development of their competencies in the provision and promotion of solutions regarding inclusive education.
\end{abstract}

Keywords: implementation of inclusive education, comprehensive education, professional competence of teacher, experience of inclusive education in pedagogical practice.

\section{Introduction}

All students require quality education regardless of their abilities and disabilities, yet is has been a challenge to offer students in Latvian schools such education for the past several decades. Notably, one of the most crucial principles in education is inclusive education. The concept of inclusive education is also linked to high expectations, societal ideals and a problematic, insufficient support situation in particular classroom environments. The latest research on the state of 
inclusive education in Latvia indicates that its system is in an early stage of development. Targeted and systematic actions in this direction have been launched relatively recently; with several solutions having emerged that are not yet systemic (Beizìtere, Grumolte-Lerhe, Ziemane, Valtenbergs, 2020). They include changes at various education systems' levels-from education policy to the practices of individual schools to a need for diverse resources. In the implementation of the approach of inclusive education in schools, the teacher's attitude, understanding and readiness to work within the inclusive education approach is of great importance. Introducing changes regarding implementing inclusive education can be done by new teachers trained in that area.

Accordingly, the current study document future teachers' perceptions regarding the concept of inclusive education. Additionally, the study investigates future teachers' experiences in using the concept of inclusive education to guide their delivery of educative content to students along with what they view as advantages or threats to the implementation of education of high standards. Therefore, identifying the main challenges in preparing teachers for inclusive education helps in promoting and developing their competencies.

\section{Literature Review}

Ideas of inclusive education started in the 20th century. Rapid developments such as the Salamanca Declaration (UNESCO, 1994) followed the adoption of the United Nations Declaration of Human Rights (UN, 1948). The Salamanca Declaration focuses on tailoring education systems on each pupil's needs. The understanding of the concept itself has also changed in the course development of society and politics. An inclusive education concept is a process for addressing all diverse educational needs, increasing opportunities for everyone to participate in learning, culture, and reducing the exclusion of the uneducated (UN, 2006; Thomas, 2013; UNESCO, 2017; Rozenfelde, 2017). Therefore, equality is one of the most important principles characterizing the concept of inclusive education. Equality is characterized by components such as fair treatment, dignity, and equal access to resources (Murray, Urban, 2012). It also covers social, cultural and ethical aspects (Allan, 2012).

Hindrances to equality in education are different national, cultural and historical experiences, educational goals, and availabilities of resources (Artiles, Kozleski, Waitoller, 2011). For equality in education to be achieved, a country must develop inclusive and equitable policies for reducing the disparities in the way education systems, forms of learning, learning environments and assessments of student achievement are now organized (UNESCO, 2017). Institutions that implement the principle of equality create environments that respect and value individual differences; they promote a school culture that reduces bias and 
eliminates systemic inequalities. Arguably, students must not be taught the same thing for equal opportunities in education to be realized. It means that everyone has the same opportunities to learn. Booth and Ainscow developed the Inclusive Education Index, which allows schools to be assessed as inclusive institutions in three dimensions:

- $\quad$ building inclusive cultures,

- development of inclusive policies, and

- development of inclusive practice (Booth, Ainscow, 2002).

Creating an inclusive learning environment requires consideration of factors at all school levels: the real commitment and action of the school administration, the collective work of teachers of inclusive culture, the purposeful work of support teams, regular communication between teachers and parents, scheduled meetings to plan and assess the use of peer-centred teaching methods, parental involvement and support, the provision of an individual education plan for every special needs' pupil and a competent teacher to adapt the curriculum and teaching methods (Rose, Tilstone, 2003; Higgins, MacArthur, Kelly, 2009; Coughlan, Lister, Seale, Scanlon, Weller, 2019; McConlogue, 2020; Allan, Jørgensen, 2021).

Teachers are the most important factors influencing how students succeed in school. Teacher competence has a crucial role in achieving positive outcomes in inclusion education (Hattie 2009; Hanushek 2014). However, there are concerns that an inclusive approach in educational institutions is difficult to implement and that teachers are not well prepared and do not receive sufficient support.

This is a major challenge for educators seeking to create an inclusive environment in schools or to teach inclusively in a particular classroom (Allan, 2012). Teachers, for example, claim that they do not have suitable working conditions to deal with visa-inclusive education, which can contribute to teacher overload and burnout. A link exists between the emotional intensity of teacher burnout and the emotional intensity of receiving public support (Fiorilli, Albanese, Gabola, Pepe, 2017). This indicates that schools should have not only a support system for students but also for teachers.

Successfully implementing inclusive education concept requires diverse competencies of teachers. The European Agency for Special Needs Education has formulated the guidelines for preparing teachers for an inclusive classroom in their practice. They specify an inclusive teacher profile with four core values and competences: assessing learner diversity, supporting all learners, collaboration between and within teams and personal professional development (European Agency for Development in Special Needs Education, 2012).

The signs showing the possibilities of a teacher meeting the diverse needs of students are positive experience with diversity and positive attitude concerning inclusive attitude (Saloviita, 2018) According to H. Savolainen, O.-P. Malinen 
and S. Schwab (2020) during pre-service teacher preparation, successful teaching experiences in an inclusive class may be a powerful way to improve efficacy and thereby shift the attitudes of prospective teachers in a more positive direction.

Currently, there is a growing demand for teachers support and professional development, which motivates teachers to participate in and develop inclusive schools and also enhancing their competence.

\section{Methodology}

This study was conducted to shed light on inclusive learning among students in Latvia by consideringthe perspectives of future teachers. Specifically, the research questions governing the study were:

1) What are the merits and demerits of inclusive education from the perspective of future teachers?

2) How do future teachers describe their experience and knowledge on inclusive education?

To address these research questions exhaustively, data werecollected through online asynchronous discussions from education students who were already involved in teaching pupils in private and public general education schools. It is noteworthy to mention that one of the study participants was a teacher in a vocational school. The participants included 61 students in the workbased teacher education study programme and 46 future pre-school and primary school teachers atthe University of Latvia. Future teachers were chosen because discussion relies on the ability and capacity of participants to provide relevant information. Importantly, the study was qualitativeto allow the researcher to capture the exact sentiments of the future teachers regarding inclusive education. An explorative research design was employed by the study team to help understand future teachers' views regarding inclusive education in Latvian schools.

The qualitative data analysis software NVivo (Release 1.3) was used to organise and analyse the close-reading (line-by-line coding) of 257 asynchronousdiscussion board entries (34,615 words) based on driving research questions. NVivo was chosen because it met the requirements, i.e., it works well with most research designs and analytical approaches and ensures easy, effective, and efficient coding, which makes retrieval easier. (Bezeley, 2007). To avoid bias, inductive coding was used to find the appropriate codesthatbest represented key points in thestudy data. Under the inductive approach, all the coded discussion entries fit into three thematic categories with six subcategories: experience and understanding of inclusive education, advantages of inclusive education (subcodes: equality and equal participation, new experience and socialization, mutuality, and acceptance) and disadvantages of inclusive education (subcodes: 
special students need special classrooms, work overload, unequal treatment). Some students' postings fit into two or more categories; these postings were coded as many times as they were represented. The data analysis was conducted from November 2020 to January 2021.

Limitations of the study design reliance on students's own descriptions of their perceptions and practice inclusive education experience. Moreover, the collected data from the included participants were not validated through other observable, objective assessments. Anonymity was used during the collection of data to protect participants' identity to mitigate potential bias. Data were collected from only one faculty of University of Latvia. Students working in different types of institutions, may have divergent perspectives about inclusive education or respond differently to an inclusive education experience than the participants in this study. Future research could explore the impact of future teachers professional experiences with diverse pupils on their perspective on inclusive education.

\section{Research Results}

\section{Experience and understanding of inclusive education}

The data collected from the involved subjects confirms the existence of controversy about Inclusive education in Latvia. Inclusive education revolves around bringing the support services to the child rather than taking the child to the services.

A majority of the responses showed negative attitude of the teachers involved concerning inclusive learning in Latvia. Equally, a majority of the participants also argued that inclusive learning in Latvia is only possible on paper but not physically doable. Some students expresed this controversal view (which was strongly supported by other prospective teachers) as follows:

What can be observed at the moment is the fact that the burden would be on the "ordinary" teachers, notwithstanding the already heavy workload, and "on paper", public officials postulate that Latvia implements inclusive education catering for the diverse needs of students. The truth is quite different in ordinary schools. (R:51)

The participants involved in the study felt that inclusive learning would do more harm than good to teachers and students, with higher chances of teachers being overworked and special needs students likely to miss out. Nevertheless, the few that had worked in schools implementing inclusive learning mentioned that they warmed up the concept, despite it being quite a task. They also categorically stated that Latvia lacks specially trained personnel to handle the pressure and keep learning in inclusive classrooms guided by appropriate classroom dynamics. This lack of support can be illustrated with a quote from some other students' opinions: 
In Latvia, there is a lack of specialists and institutions that could explain how to recognize learning disabilities in general education institutions. Thus, the problem deepens and students continue to learn the subject according to the current methodologies. (R:14)

Reality: there are 30 students in the class (for all of whom the right, individual approach is desirable.) The teacher leads lesson one, has to prepare different tasks for one class with no additional resources, the lesson is 40 minutes, (...) that the teacher's paid salary does not cover (...) So, figuratively speaking, we want the horse to pull carriage that lack wheels. Yes, the strongest are able! But such circumstances should not be the norm! (R:26)

One thing is certain: inclusive learning in Latvia is likely to wear the teachers out if they are not given proper training. Angrily, one of the respondents stated, "In Latvia, in my opinion, teachers often have to be "born superheroes"-

HAVE TO KNOW, WORK, PREPARE, DO, GET, PROVIDE, RESPOND?? (R:26). This confirms some teachers lack necessary resources to help support engagements in inclusive learning.

\section{Advantages of inclusive education}

\section{1) Equality and equal participation}

The response by a majority of participants showed that inclusive education allows children of all races, social statuses, nationalities, genders, religions, political beliefs, health statuses, and places of residence to receive better education, which promotes equality for all. For example, a participant said:

Inclusive education emphasizes on granting all students equal rights notwithstanding their abilities interests, needs and capabilities. It also gives them the acquisition of quality education and, in the future, an opportunity to study at university, learn a profession, and become an independent member of society, which affects their quality of life. (R:17)

Another added, "Irrespective of the pupil's educational and development needs and abilities... they are entitled to receive a basic education" (R:38). Equally, a respondent mentioned that both "normal" and students with special needs are offered equal participation through inclusive learning, thereby leading to the enrichment of special needs students in the areas of self-esteem and selfconfidence due to the same platform of learning, socializing and expressing opinions. This, in return, creates an environment of growth and enriched learning. In support of the argument, a participant said, "Everyone is given equal chance to take part in any subject taught in class” (R:43).

Special needs students or students with learning disabilities, through inclusive education, share a classroom with other children. This gives the children the opportunity to pursue and achieve their dreams as any other child. In support of this, one of the respondents stated, "Combating discrimination is only possible in ordinary schools implementing the approach of inclusive education creating 
inclusive environment that further builds an inclusive system of education for all.” (R:52).

\section{2) New experience and socialization}

Inclusive learning has been considered foreign and bizarre to many, not only in Latvia but across the globe. This is because it is a new mode of education that deviates from the regular education system, wherein the "normal" children attend regular school while those with disabilities or special needs attend special schools. Therefore, its introduction has not only been a new experience to teachers but also to students. As a result, learners with distinct learning disabilities can socialize and even grow socially with other students. Additionally, through socialization facilitated by inclusiveness, students with disabilities can identify their own role models amongst other students, which can facilitate conversations, relaying information, and social and adaptive behaviour - a developmental aspect that is may be lacking or developing at a slower pace for special needs children when excluded. Based on the stated reason one participant said, "I believe that the advantages of inclusive education for the child are to feel safe and accepted" (R:9), while another added:

Special children can expand their circle of contact with people without developmental disabilities of different ages, which increases their levels of socialization and communicative skills. It promotes attention, responsiveness, and readiness to come to the rescue. Ordinary children learn to respect and appreciate their classmates, to see what is behind the external features and manifestations of disability. (R:22).

\section{3) Mutuality and Acceptance}

One of the most outstanding advantages of inclusive education in Latvia is that it brings about mutuality, especially for students with special needs. Mutuality can be defined as a feeling of fulfilment that is experienced by parties in a relationship. Mutuality can further be subdivided into trust, caring for each otherand having a mutual understanding. Often, inclusive education brings about trust, care and mutual understanding amongst students. This is only possible when the students learn to accept each other's differences and get past them. In favour of inclusive learning, one of the participants stated:

Inclusion means celebrating difference and diversity. It introduces a culture in which all people are equally valued, and all feel accepted. Inclusion and participation are necessary for an individual's socio-emotional development. (R:16)

\section{Disadvantages of inclusive learning \\ 1) Special students need special classrooms}

For maximum benefit of the education system, special needs students need classroom settings adapted to meet their needs, which is a core disadvantage of implementing the concept of inclusive education. A notable occurrence is that 
children with learning disabilities lag behind when receiving instructions in an inclusive classroom. The situation also slows down normal students in their learning since the teacher must constantly ensure the students with learning disabilities are at par with the regular students by repeating concepts. In special schools, the classes are small, with limited distractions and more one-on-one instruction. This creates an individualized learning environment, which brings out the maximum potential of students with disabilities. It is for this reason that a majority of the participants to the study conducted argued that inclusive education needs to have a better link with technical and human resources:

I can also say from my personal experience that I am afraid of the unknown and, of course, of inclusive education. Therefore, as a solution to successfully implementing inclusive education is appropriately preparing future teachers on inclusive education strategies as well as attracting teachers in practice. Attracting existing teachers with experience and competence help reduce teachers' concerns about their abilities in delivering contents in inclusive classrooms and demonstrating daily practical experience and practical work, thereby promoting attitudinal change. (R:53)

\section{2) Work Overload}

Regular school teachers are only trained to teach and impart knowledge to regular students. In contrast, teachers for special needs students are specifically trained impart knowledge to special needs students. Consequently, regular teachers in inclusive classrooms need to be trained to pass on knowledge to special needs students effectively. Hence, this teacher will dedicate needed time to help student with learning disabilities for them to be at par with the other students in class. Such means of engagement make the teachers be overworked. Along the same lines, one of the respondents stated,

The lesson is only 40 minutes long and a teacher must adapt materials, hold students' attention, which is a challenge in any case, and still be able to approach children with special needs individually, because if special needs students do not complete their work and gain needed competence, the assessment system will highlight the weakness of the teacher providing classroom instructions to students in an inclusive classroom. (R:1)

\section{3) Unequal treatment}

Inclusive education in Latvia is likely to bring about unfair treatment of children in an inclusive classroom. In view of this, one of the respondents emphatically stated,

Differentiated tasks in students raise concerns about unequal treatment - why does he only have to write seven sentences if I have 10? And for a 10-year-old at 8 a.m., there is a difficulty in explaining that "if you are able to perform better, you will be asked to do more.” (R:36) 
Equally, "it is not necessary to divide them separately only according to specific subjects, but to put all the divisions" in one bag and such groupings should be due to their abilities and interests in general" (R:36). To expound on this, special needs students are likely to be given more attention and taken care of by teachers, unlike regular students. This is likely to create segregation among the students, as some students might fail to understand why those with special needs receive less criticism, less homework or more attention.

\section{Conclusions}

Inclusive learning is a topic of discussion and research not only in Latvia but across the whole of Europe. Special educators, regular educators and administrators continue to have mixed feelings towards inclusion. What is certain among future teachers is that a successful, inclusive education practice in Latvia demandsproper resources and training to facilitate a smooth transition. This way, teachers, students, and parents will maintain an optimistic view about it. Otherwise, inclusive learning might only remain on paper.

In conclusion, we can strive to support the inclusive educationof all students along with the learning processes of future teachers, develop diverse teacher competencies to recognize students' special needs, use and adapt diverse teaching methods, developemotional competence, and proactively seek help withcompliance.

\section{Acknowledgements}

We are grateful to the students of the work-based teacher education programmeand Primary education programmeof the University of Latvia for active participation in the open discussion on inclusive education.

\section{References}

Allan, J. (2012). Thinking again about inclusion. In A Arnesen (ed.), Including. Perspectives in kindergarten practice. Oslo: Universitetsforlaget.

Allan, J., \& Jørgensen, C. (2021). Inclusive School Development: The First Years of an English Free School. In Köpfer A., Powell J., \& Zahnd R. (Eds.), Handbuch Inklusion international / International Handbook of Inclusive Education: Globale, nationale und lokale Perspektiven auf Inklusive Bildung / Global, National and Local Perspectives (pp. 329-344). Opladen; Berlin; Toronto: Verlag Barbara Budrich.

Artiles, A. J., Kozleski, E. B., Waitoller, F.R. (Eds.) (2011). Inclusive Education:Examining Equity on Five Continents. Cambridge : Harvard Education Press.

Beizītere, I., Grumolte-Lerhe,I., Ziemane,I., Valtenbergs, V. (2020). Ieklaujošā izglìtība bērniem ar speciālām vajadzībām Latvijā. Pētījuma gala ziņojums. Rīga: Latvijas Republikas Saeima. 
Bezeley, P. (2007). Qualitative Data Analysis with NVivo. London: Sage.

Booth, T., and Ainscow, M. (2002). Index for Inclusion:developing learning and participation in schools. London: Centre for Studies on Inclusive Education (CSIE)

European Agency for Development in Special Needs Education. (2012). Profile of Inclusive Teachers. Odense, Denmark: European Agency for Development in Spe-cial Needs Education.

Fiorilli, C., Albanese, O., Gabola, P., Pepe, A. (2017).Teachers' Emotional Competence and Social Support: Assessing the Mediating Role of Teacher Burnout. Scandinavian Journal of Educational Research, Volume 61, Issue 2, 4 March 2017, p.127-138

Higgins, N., MacArthur, J. \& Kelly, B. (2009). Including disabled children at school: is it really as simple as 'a, c, d'? International Journal of Inclusive Education, Volume 13, 2009 Issue 5.

McConlogue, T. (2020). Developing Inclusive Curriculum and Assessment Practices. In Assessment and Feedback in Higher Education:A Guide for Teachers. London: UCL Press, p. 137-150

Murray, C., Urban, M. (2012). Diversity and Equality in Early Childhood: An Irish Perspective. Dublin: Gill \& Macmillan.

Rose, R., Tilstone, C. (2003).Strategies to Promote Inclusive Practice. Routledge.

Rozenfelde, M. (2016). Skolēnu ar speciālajām vajadzībām iekḷaušanas vispārējās izglìtības iestādēs atbalsta sistēma. Promocijas darbs. Rīga: Latvijas Universitāte. Retrieved from:https://dspace.lu.lv/dspace/bitstream/handle/7/32003/298-55964-

Rozenfelde_Marite_mr16007.pdf?sequence $=1 \&$ isAllowed $=\mathrm{y}$

Saloviita, T. (2018). Attitudes of Teachers Towards Inclusive Education in Finland. Scandinavian Journal of Educational Research, Vol. 64(2), 270-282.

Savolainen, H., Malinen, O.-P. \& Schwab, S. (2020). Teacher efficacy predictsteachers'attitudes towards inclusion - a longitudinal cross-lagged analysis, International Journal of Inclusive Education. Retrived from: https://www.tandfonline.com/doi/full/10.1080/13603116.2020.1752826

Thomas, G. (2013). A Review of Thinking and Research about Inclusive Education Policy, with Suggestions for a New Kind of Inclusive Thinking. British Educational Research Journal, 39(3), 473-490.

UNESCO. (1994). The Salamanca Statement and Framework for Action on Special Needs Education. Retrieved from: https://unesdoc.unesco.org/ark:/48223/pf0000098427

UNESCO. (2017). A guideforensuring inclusion and equity in education. Retrieved from: https://unesdoc.unesco.org/ark:/48223/pf0000248254

United Nations UN. (1948). The Universal Declaration of Human Rights. Retrieved from https://www.un.org/en/universal-declaration-human-rights/

United Nations (UN). (2006). Convention on the Rights of Persons with Disabilities. United Nations. Retrieved from https://www.un.org/development/desa/disabilities/conventionon-the-rights-of-persons-with-disabilities.html 